\title{
Identification of Single Nucleotide Polymorphisms in PRNP Gene of Korean Native Goats
}

\author{
Md. Rashedul Hoque*, Seong Lan Yu*, Seong Heum Yeon** and Jun Heon Lee* \\ Department of Animal Science and Biotechnology, College of Agriculture and Life Sciences, Chungnam National University*, \\ National Institute of Animal Science, R.D.A., Namwon, Korea**
}

\begin{abstract}
Prion protein (PRNP) is known to be a causative protein for transmissible spongiform encephalopathy (TSE), a disease occurring in human and animals. Previous results indicate that the genetic variability can affect the resistance and susceptibility of goat scrapie and can give the guideline for reducing the risk of this disease. Until now, 35 single nucleotide polymorphisms (SNPs) were identified in goat PRNP gene from many countries such as Great Britain, Italy, United States of America and Asian countries etc. In this study, SNPs in PRNP gene have been investigated to research the PRNP variations and their possible TSE risks in 60 Korean native goats. Based on the sequencing results, we identified four SNPs and three of those polymorphisms (G126A, C414T and C718T) were synonymous and the A428G polymorphism was non-synonymous which changes the amino acid histidine to arginine. Previously, all of these four SNPs were identified in Asian native goats. Specifically, five polymorphisms were identified in Asian native goats and two of them (G126A and C414T) were silent mutations, and the other SNPs (T304G, A428G and T718C) caused amino acid changes (W102G, H143R and S240P). Comparing with SNP results from other breeds, this study is an initial step to understand resistance and susceptibility of this disease in Korean native goats.

(Key words : Korean native goats, Prion protein (PRNP), Single nucleotide polymorphism (SNP), Transmissible spongiform encephalopathy (TSE))
\end{abstract}

\section{INTRODUCTION}

Prion protein (PRNP) is responsible for scrapie as a neurodegenerative disease affecting cattle, sheep and goats. The scrapie is also called as transmissible spongiform encephalopahies (TSEs). This illness in cattle is called bovine spongiform encephalopathy (BSE) and highly related to the human neurodegenerative disease, called Creutzfeldt-Jakob disease (CJD). Prions are infectious protein molecules that can be characterized by $\operatorname{PrP}^{\mathrm{sc}}$ accumulation in central nervous system (CNS) in all hosts-encoded prion protein $\left(\operatorname{PrP}^{\mathrm{c}}\right)(\mathrm{Oesch}$ et al., 1985; Prusiner and De Armond 1994; Prusiner, 1998) and in the lympho-reticular system (LRS) (Ikegami et al., 1991; Muramatsu et al., 1992). $\operatorname{PrP}^{\mathrm{sc}}$ is an infectious glycoprotein derived from cellular protease-sensitive isoform $\left(\mathrm{PrP}^{\mathrm{c}}\right)$ that is an encoded glycoprotein in the host genome by PRNP gene (Prusiner, 2004).

The genetic resistance or susceptibility to scrapie is highly associated with genotype (A136V, R154H and Q171R/H) to the host and infectious strain of $\operatorname{PrP}^{\text {sc }}$ that results have the haplotypes reported as susceptible type (Ala-Arg-Gln) in sheep (Baylis and Goldmann, 2004). The effect of polymorphisms to scrapie has been associated with mutations in the coding region of the gene that is encoded by a single-copy autosomal gene (PRNP) (Prusiner, 1998). Amino acid polymorphism at codon 142 has been reported in UK goats to be associated with disease incubation period (Goldmann et al., 1996). Whereas, another study suggested that PRNP alleles are carrying arginine at codon 143 and histidine at codon 154 may offer some protective roles against scrapie in Greek goats (Billinis et al., 2002). Others suggested the polymorphisms at codons $142 \mathrm{M}$ and $143 \mathrm{R}$, which were associated with the resistance to scrapie in Japanese goat (Kurosaki et al., 2005). However, polymorphisms located at codons 142, 143, 146, 154 and 222 were found to be associated with scrapie protective effect to prion disease and were reported for goats from the UK, Greece, Cyprus and Italy (Goldmann et al., 1996; Billinis et al., 2002; Acutis et al., 2006; Vaccari et al., 2006; PapasavvaStylianou et al., 2007). Zhang et al. (2004) reported eight amino acid polymorphisms in Chinese goats, including few

Corresponding author:Dr. J. H. Lee, Department of Animal Science and Biotechnology, College of Agriculture and Life Sciences Chungnam National University, Daejeon 305-764, Korea. Tel: 82-42-821-5779, Fax: 82-42-825-9754, Email: junheon@cnu.ac.kr 
polymorphisms in the main breeds of indigenous Chinese goats of PRNP gene (Zhou et al., 2008). Twelve alleles were determined in goats from Italian scrapie outbreaks (Acutis et $a l ., 2006)$ and also the genetic variability of the PRNP gene in Italian goats has been investigated (Acutis et al., 2008). Also, ten breeds in US (White et al., 2008), four breeds in Pakistan (Babar et al., 2009) and two breeds in Morocco (Serrano et al., 2009) have been investigated for the polymorphisms in PRNP gene and ten, five and ten SNPs were identified, respectively. Recently, Barillet et al. (2009) reported seven haplotypes of the caprine PRNP gene at codons 127, 142, 154, 211, 222 and 240 in two French goat breeds and their associations were investigated with classical scrapie. However, so far only five polymorphisms were identified in Asian native goats. More precisely, two polymorphisms (G126A and C414T) where the silent mutations, and the other three (T304G, A428G and T718C) caused amino acid changes (W102G, H143R and S240P) (Sasazaki et al., 2008).

Recently, the number of studies investigating the goat PRNP gene has increased due to animal and human health issues. Therefore the aim of this study was to investigate PRNP polymorphisms in Korean native goats in order to assess the susceptibility and resistance of the scrapie in this native species.

\section{MATERIALS AND METHODS}

\section{Animals and genomic DNA extraction}

Genomic DNA samples from 60 Korean native goats (from 20 animals each for three lines) were used for this investigation. Blood samples were collected from National Institute of Animal Science (NIAS), Korea, in a sampling tube containing EDTA as an anticoagulant and placed on ice for subsequent DNA extraction. Genomic DNA was extracted using PrimePrep ${ }^{\mathrm{TM}}$ Genomic DNA Isolation Kit (GeNet Bio, Korea) according to the manufacturer's instruction.

\section{Primer design and PCR amplification}

Table 1. Primer sequences, PCR product sizes and corresponding annealing temperatures for identification of the polymorphisms in caprine PRNP gene

\begin{tabular}{|c|c|c|c|c|}
\hline $\begin{array}{c}\text { Primer } \\
\text { name }\end{array}$ & Forward primer sequence ( $5 /$ to $3 /)$ & Reverse primer sequence ( $5 /$ to $3 /)$ & $\begin{array}{l}\text { Product size } \\
\text { (bp) }\end{array}$ & $\begin{array}{c}\text { Annealing temp } \\
\left({ }^{\circ} \mathrm{C}\right)\end{array}$ \\
\hline PRNP 1 & TGTTTATAGCTGATGCCACTGC & CCTCATAGTCATTGCCAAAATG & 560 & 59 \\
\hline PRNP 2 & CAAGGTGGTAGCCACAGTCA & ACAGGGCTGCAGGTAGACAC & 564 & 59 \\
\hline
\end{tabular}

Primers were designed from ovis sequence data (GenBank accession no. U67922) which is aligned with capra ORF region (GenBank accession no. EF140716) and two primer sets were considered to amplify coding region of the PRNP gene. The information for primer sequences, product sizes and annealing temperatures is shown in Table 1 . The PCR reaction mixture included approximately $50 \mathrm{ng}$ of genomic DNA, $2.5 \mu \mathrm{l} 10 \mathrm{X}$ PCR Gold Buffer (100 mM Tris-HCl, pH 8.3, $500 \mathrm{mM} \mathrm{KCl}$ ), $1.5 \mu 125 \mathrm{mM} \mathrm{MgCl}_{2}, 2 \mu \mathrm{l}$ of each dNTPs $(2.5 \mathrm{mM}), 1 \mu \mathrm{l}$ of each primer (10 pM) and $1 \mathrm{U}$ Taq polymerase (AmpliTaq Gold $^{\mathrm{TM}}$, Applied Biosystems, USA) in a $20 \mu \mathrm{l}$ reaction volume. The PCR reaction was performed in a GeneAmp 2700 thermocycler (Applied Biosystems, USA) with an initial denaturation step at $94^{\circ} \mathrm{C}$ for 5 min followed by 35 cycles of $40 \mathrm{sec}$ at $94^{\circ} \mathrm{C}, 40 \mathrm{sec}$ at a specific annealing temperature for each primer set (Table 1), $40 \mathrm{sec}$ at $72^{\circ} \mathrm{C}$ and a final step of extension at $72^{\circ} \mathrm{C}$ for $7 \mathrm{~min}$. All the PCR products were run on $1.5 \%$ agarose gels stained with ethidium bromide and DNA bands were visualized under UV light.

\section{DNA sequencing and genotyping}

DNA sequencing was performed in the PRNP coding region using 60 samples from Korean native goats. In order to preliminary identify the SNPs, three DNA samples were mixed and the polymorphisms were investigated. Purification of PCR products using Accuprep ${ }^{\circledR}$ PCR purification kit (Bioneer, Korea) was conducted in according to the manufacturer's instructions. Purified PCR products were sequenced by Genotech (www.genotech.co.kr) and polymorphisms were searched using Chromas program (Technelysium Pvt. Ltd., Australia). To verify the identified SNPs, restriction enzymes were selected from New England Biolabs (http://www.neb. com). The digested PCR products were separated on $3 \%$ agarose gels stained with ethidium bromide and the DNA fragments were visualized under UV light. Based on the PCRRFLP patterns, genotype and allele frequencies were also investigated. 


\section{Sequence analysis}

Mutations were detected from the sequences data using Chromas program and existing sequences were extracted from the NCBI database (http://www.ncbi.nlm.nih.gov). ClustalW program (http://www.ebi.ac.uk/Tools/clustalw2/index.html) was performed by alignment of multiple sequences and the mutations were scored using MEGA software (MEGA4, Tamura et al., 2007). Amino acid sequences were deducted using the Open Reading Frame Finder at NCBI (http://www. ncbi.nlm.nih.gov/gorf/gorf.html). Allele frequencies of each SNP were compared by chi-square test $\left(\chi^{2}\right)$ within the Korean native goats. Linkage disequilibrium(LD), blocks and haplotypes were inferred using the algorithm developed by the Broad Institute (Haploview, USA).

\section{RESULTS}

The caprine PRNP gene has 771 bp coding sequences with a single exon. Previously, Lee et al. (1998) compared that caprine PRNP coding sequence was completely matched to the reference ovis sequences which was also used to detect polymorphisms in goats. The current results indicated that Korean native goats have four of previously reported mutations in the PRNP coding region. Three of those polymorphisms (G126A, C414T and C718T) were silent mutations and their

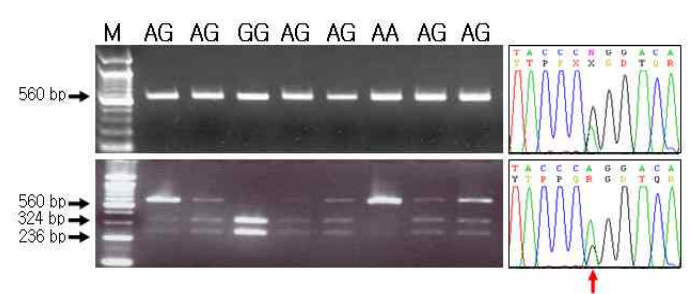

(A)

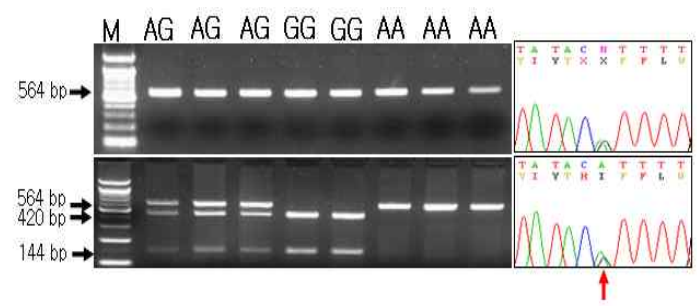

(C) codons are P42, S138 and P240, respectively. Another polymorphism at $\mathrm{A} 428 \mathrm{G}$, caused amino acid changes from histidine to arginine (H143R) (Fig. 1). These polymorphisms were confirmed by PCR-RFLP methods (Table 2). Genotype and allele frequencies were calculated and used to assess each SNP comparison by Hardy-Weinberg equilibrium test ( $\chi^{2}$ test) within the Korean native goats (Table 3).

Haplotype association analyses were performed to identify PRNP polymorphisms which include four major haplotypes with frequency $>0.05$ (Table 4). One low frequency ATGC haplotype was not considered for haplotype associations. The GTGC haplotype (ht1) has highest haplotype frequency $(37.5 \%)$. On the other hand, the frequencies of GTAC haplotype (ht2) and ACAT haplotype (ht3) were $24.2 \%$ and $22.5 \%$, respectively. The ATAC haplotype $4(\mathrm{ht} 4)$ contained the lowest frequency of $10.6 \%$. Different allele frequencies

Table 2. Identified polymorphisms in PRNP gene and restriction enzymes used for the SNP confirmation in Korean native goats

\begin{tabular}{ccc}
\hline $\begin{array}{c}\text { SNP position in ORF } \\
\text { region }\end{array}$ & $\begin{array}{c}\text { Amino acid } \\
\text { change }\end{array}$ & $\begin{array}{c}\text { Restriction } \\
\text { enzyme }\end{array}$ \\
\hline \hline $126 \mathrm{G}>\mathrm{A}$ & Silent & Nci I \\
$414 \mathrm{C}>\mathrm{T}$ & Silent & Cac8 I \\
$428 \mathrm{~A}>\mathrm{G}$ & Missense & HpyCH4IV \\
$718 \mathrm{C}>\mathrm{T}$ & Silent & Mbo П \\
\hline
\end{tabular}

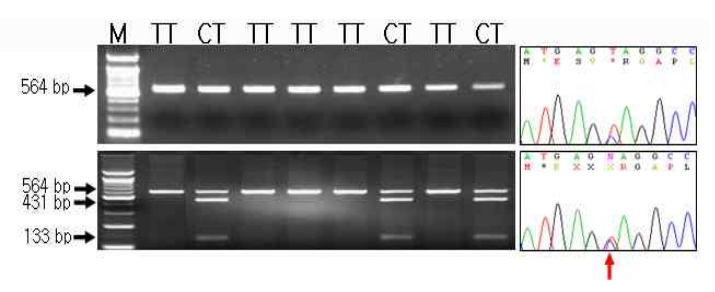

(B)

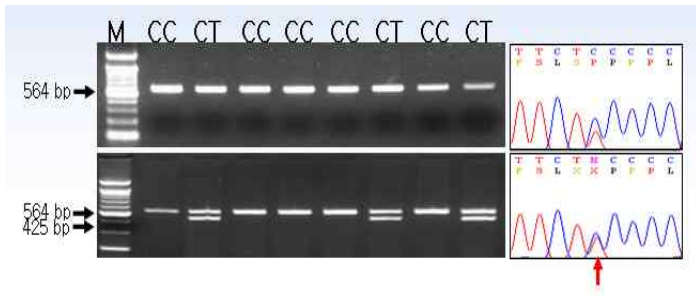

(D)

Fig. 1. PCR-RFLP patterns for SNPs in PRNP gene in Korean native goats. The gel image A represents g.126 G>A mutation (digestion with Nci I ), B for g. 414 C>T mutation (with Cac8 I ), C for g.428 A>G mutation (with $\mathrm{HpyCH} 4 \mathrm{IV}$ ) and $\mathrm{D}$ for $718 \mathrm{C}>\mathrm{T}$ mutation. Arrows in the chromatograms indicate the polymorphic sites. M: 100bp molecular size marker (ELPIS, Korea). 
Table 3. Genotype and allele frequencies of four identified polymorphisms in PRNP gene in Korean native goats

\begin{tabular}{ccccccc}
\hline SNP Position & \multicolumn{3}{c}{$\begin{array}{c}\text { Genotype frequency } \\
\text { (No. of goats) }\end{array}$} & $\begin{array}{c}\text { Total } \\
\text { No. of goats }\end{array}$ & Allele frequency & $\begin{array}{c}\mathrm{X}^{2} \text { test } \\
\text { (HW equilibrium test) }\end{array}$ \\
\hline \hline 126 G>A & $\begin{array}{c}\text { GG0.333 } \\
(20)\end{array}$ & $\begin{array}{c}\text { GA0.567 } \\
(34)\end{array}$ & $\begin{array}{c}\text { AA0.1 } \\
(6)\end{array}$ & 60 & G0.617/A0.383 & N. S. \\
\hline $414 \mathrm{C}>\mathrm{T}$ & $\begin{array}{c}\mathrm{TT} 0.567 \\
(34)\end{array}$ & $\begin{array}{c}\mathrm{CT} 0.416 \\
(25)\end{array}$ & $\begin{array}{c}\mathrm{CC} 0.017 \\
(1)\end{array}$ & 60 & T0.775/C0.225 & N. S. \\
\hline $428 \mathrm{~A}>\mathrm{G}$ & $\begin{array}{c}\mathrm{AA} 0.288 \\
(17)\end{array}$ & $\begin{array}{c}\mathrm{AG} 0.593 \\
(35)\end{array}$ & $\begin{array}{c}\mathrm{GG} 0.119 \\
(7)\end{array}$ & 59 & $\mathrm{~A} 0.585 / \mathrm{G} 0.415$ & N. S. \\
\hline $718 \mathrm{C}>\mathrm{T}$ & $\begin{array}{c}\mathrm{CC} 0.55 \\
(33)\end{array}$ & $\begin{array}{c}\mathrm{CT} 0.433 \\
(26)\end{array}$ & $\begin{array}{c}\mathrm{TT} 0.017 \\
(1)\end{array}$ & 60 & $\mathrm{C} 0.767 / \mathrm{T} 0.233$ & N. S. \\
\hline
\end{tabular}

1) N. S. means not significant

Table 4. Haplotypes in PRNP gene in Korean native goats

\begin{tabular}{cccccc}
\hline & \multicolumn{5}{c}{ Haplotypes } \\
\cline { 2 - 5 } & G126A & C414T & A428G & C718T & Frequency \\
\hline \hline ht1* & G & T & G & C & 0.375 \\
ht2 & G & T & A & C & 0.242 \\
ht3 & A & C & A & T & 0.225 \\
ht4 & A & T & A & C & 0.106 \\
Other & A & T & G & C & 0.044 \\
\hline
\end{tabular}

* ht means haplotype.

among these polymorphisms have been observed previously in few Asian countries (Sasazaki et al., 2008). The highest linkage disequilibrium coefficient $\left(\mathrm{r}^{2}\right)$ value of 0.954 indicated that SNPs C414T and C718T had strong linkage in block 1. In the haplotype block 1 , the highest frequency was appeared in TC (76.7\%) and the lowest was CT (22.5\%) haplotype (Table 5). Other two polymorphisms (G126A and A428G) were not considered with LD. We determined Lewontin's D' (1D'l) and the $r^{2}$ between all pairs of biallelic loci in PRNP region in Korean native goats (Table 6). The pair-wise $\mathrm{D}^{\prime}$ values of the SNPs were generally above 0.90 and $\mathrm{r}^{2}$ values more than 0.20 is considered for this LD analysis.

Table 5. The information for haplotype block 1 in PRNP gene in Korean native goats

\begin{tabular}{|c|c|c|c|}
\hline & \multicolumn{2}{|c|}{ Hap Block 1} & \multirow{2}{*}{ Freq } \\
\hline & $\mathrm{C} 414 \mathrm{~T}$ & $\mathrm{C} 718 \mathrm{~T}$ & \\
\hline ht1, ht2, ht4 & $\mathrm{T}$ & $\mathrm{C}$ & 0.767 \\
\hline ht3 & $\mathrm{C}$ & $\mathrm{T}$ & 0.225 \\
\hline
\end{tabular}

\section{DISCUSSION}

SNPs in relation to resistance and susceptibility against scrapie in goat polymorphisms have been documented in a number of studies, namely W102G, I142M, H143R, N146S/D, R154H, R211Q and Q222K (Goldmann et al., 1996; Goldmann et al., 1998; Billinis et al., 2002; Kurosaki et al., 2005; Acutis et al., 2006; Vaccari et al., 2006; Papasavva-Stylianou et al., 2007; White et al., 2008; Zhou et al., 2008; Barillet et al., 2009; Serrano et al., 2009). Different kind of protein variation was found in a series of glycine-rich octa- or nonapeptide sequences in the N-terminal region of the PRNP protein. In the PRNP coding region, octa- and nonapeptide repeat number variants contain only three instead of the normal five copies of short peptide repeat [Pro-Gln/His-Gly-Gly-Gly-(Gly)-TrpGly-Gln] (Goldmann et al., 1998). They also reported three copies of peptide repeats that were associated with incubation periods of scrapie in Italian goats. Whereas, Asi Asi Asi Asi Asihad five copies of these peptide repeats consisted of three octapeptides and two nonapeptides (Sasazaki et al., 2008). 
Based on the comparison with o1998 studies, A126G (P42) and C414T (S138) polymorphisms were linked to codon S240P (Goldmann et al., 1996; Kurosaki et al., 2005; Acutis et al., 2006; Bcia8 et al., 2009). Therefas,, ou8 results showed that the codon $240 \mathrm{P}$ is a silenn outation and this $\mathrm{c}$ Asbe linked to $126 \mathrm{G}$ and $414 \mathrm{~T}$ SNPs. Several studies have investigated this phenomenon in different goat breeds, which sugtssted that PRNP alleles carrying argininte(R) at codon 143 may off98 resistance against scrapiee(Billinis et al., 2002; Vaccari et al., 2006; White et al., 2008; Zhou et al., 2008). The presence of the amino acid $\operatorname{argininte}(\mathrm{R})$ at codon 154 and the asparaginte $(\mathrm{N})$ at codon 146 was associated with the susceptibility iAsi Aural scrapiee(Billinis et al., 2002; Papasavva- Stylianou et al., 2007). In our study, the Korean native goats also have 143R genotype which indicates the possible association with resistance against goat scrapie.

The present investigation is the preliminary study performed in Korean native goats which provide the information about alleles and genotypes of PRNP gene for resistance or susceptibility to prion disease. Further studies for the PRNP variation and prion disease are needed in order to better understand the genetics of prion disease that would help to design an ideal strategy for Korean native goats.

\section{ACKNOWLEDGEMENTS}

This study was financially supported by research fund of Chungnam National University in 2009.

\section{REFERENCES}

1. Acutis, P. L., Bossers, A., Priem, J., Riina, M. V., Peletto, S., Mazza, M., Casalone, C., Forloni, G., Ru, G. and Caramelli, M. 2006. Identification of prion protein gene polymorphisms in goats from Italian scrapie outbreaks. J. Gen. Virol. 87:10291033.

2. Acutis, P. L., Coluss, S., Santagada, G., Laurenza, C., Maniaci, M. G., Riina, M. V., Peletto, S., Goldmann, W., Bossers, A., Caramelli, M., Cristoferi, I., Maione, S., Sacchi, P. and Rasero, R. 2008. Genetic variability of the PRNP gene in goat breeds from Northern and Southern Italy. J. appl. Microbiol. 104: 1782-1789.

3. Babar, M. E., Abdullah, M., Nadeem, A. and Haq, A. U. 2009. Prion protein gene polymorphisms in four goat breeds of Pakistan. Mol. Biol. Rep. 36:141-144.

4. Barillet, F., Marita, D., Amigues, Y., Foucras, R., Caillat, H.,
Moazami-Goudarzi, K., Rupp, R., Babilliot, J. M., Lacroux, C., Lugan, S., Schelcher, F., Charter, C., Corbière, F. and Andreoletti, O. 2009. Identification of seven haplotypes of the caprine PrP gene at codons 127, 142, 154, 211, 222 and 240 in French Alpine and Saanen breeds and their association with classical scrapie. J. Gen. Virol. 90:769-776.

5. Baylis, M. and Goldmann, W. 2004. The genetics of scrapie in sheep and goats. Curr. Mol. Med. 4:385-396.

6. Billinis, C., Panagiotidis, C. H., Psychas, V., Argyroudis, S., Nicolaou, A., Leontides, S., Papadopoulos, O. and Sklaviadis, T. 2002. Prion protein gene polymorphisms in natural goat scrapie. J. Gen. Virol. 83:713-721.

7. Goldmann, W., Chong, A., Foster, J., Hope, J. and Hunter, N. 1998. The shortest known prion protein gene allele occuron protein, has only three octapeptide repeats and is nonpathogenic. J. Gen. Virol. 79(12):3173-3176.

8. Goldmannn, W., Martin, T., Foster, J., Hughes, S., Smith, G., Hughes, K., Dawson, M. and Hunter, N. 1996. Novel polymorphisms in the caprine PrP gene: a codon 142 mutation associated with scrapie incubation period. J. Gen. Virol. 77: 2885-2891.

9. Ikegami, Y., Ito, M., Isomura, H., Momotani, E., Sasaki, K., Muramatsu, Y., Ishiguro, N. and Shinagawa, M. 1991. Preclinical and clinical diagnosis of scrapie by detection of PrP protein in tissues of sheep. Vet. Rec. 128:271-275.

10. Kurosaki, Y., Ishiguro, N., Horiuchi, M. and Shinagawa, M. 2005. Polymorphisms of caprine PrP gene detected in Japan. J. Vet. Med. Sci. 67:321-323.

11. Lee, I. Y., Westaway, D., Smit, A. F. A., Wang, K., Seto, J., Chen, L., Acharya, C., Ankener, M., Baskin, D., Cooper, C., Yao, H., Prusiner, S. B. and Hood, L. E. 1998. Complete genomic sequence and analysis of the prion protein gene region from three mammalian species. Genome Res. 8(10): 1022-1037.

12. Muramatsu, Y., Tanaka, K., Horiuchi, M., Ishiguro, N., Shinagawa, M., Matsui, T. and Onodera, T. 1992. A specific RFLP type associated with the occurrence of sheep scrapie in Japan. Arch. Virol. 127:1-9.

13. Oesch, B., Westaway, D., Walchi, M. \& 9 other authors. 1985. A cellular gene encodes scrapie PrP 27-30 protein. Cell 40:735-746

14. Papasavva-Stylianou, P., Kleanthous, M., Toumazos, P., Mavrikiou, P. and Loucaides, P. 2007. Novel polymorphisms at codons 146 and 151 in the prion protein gene of Cyprus goats, and their association with natural scrapie. Vet. J. 173 (2):459-462. 
15. Prusiner S. B. and De Armond S. J. 1994. Prion diseases and neurodegeneration. Annu. Rev. Neurosci. 17:311-339.

16. Prusiner S. B. 2004. Prion biology and diseases. Cold Spring Harbor Laboratory Press, Cold Spring Harbor, NY.

17. Prusiner S. B. 1998. Prions. Proc. Natl. Acad. Sci. USA. 95:13363-13383.

18. Sasazaki, S., Nagato, T. and Mannen, H. 2008. Genetic diversity of prion protein gene in Asian native goat. Small Rumin. Res. 80:101-103.

19. Serrano, C., Hammouchi, M., Benomar, A., Lyahyai, J., Ranera, B., Acı'n, C., Hamidi, M. el., Monzo'n, M., Badiola, J. J., Tligui, N., Zaragoza, P. and Martı'n-Burriel, I. 2009. PRNP haplotype distribution in Moroccan goats. Anim. Genet. doi:10.1111/j.1365-2052.2009.01873.x.

20. Tamura, K., Dudley, J., Nei, M. and Kumar, S. 2007. MEGA4: Molecular Evolutionary Genetics Analysis (MEGA) software version 4.0. Mol. Biol. Evol. 24:1596-1599.

21. Vaccari, G., Di Bari, M. A., Morelli, L., Nonno, R.,
Chiappini, B., Antonucci, G., Marcon, S., Esposito, E., Fazzi, P., Palazzini, N., Troiano, P., Petrella, A., Di Guardo, G. and Agrimi, U. 2006. Identification of an allelic variant of the goat PrP gene associated with resistance to scrapie. J. Gen. Virol. 87:1395-1402.

22. White, S., Herrmann-Hoesing, L., O'Rourke, K., Waldron, D., Rowe, J. and Alverson, J. 2008. Prion gene (PRNP) haplotype variation in United States goat breeds. Genet. Sel. Evol. 40: 553-561.

23. Zhang, L., Li, N., Fan, B., Fang, M. and Xu, W. 2004. PRNP polymorphisms in Chinese ovine, caprine and bovine breeds. Anim. Genet. 35:457-461.

24. Zhou, R. Y., Li, X. L., Li, L. H., Wang, H. Y. and Lu, J. G. 2008. Polymorphism of the PRNP gene in the main breeds of indigenous Chinese goats. Arch. Virol. 153:979-982.

(Received September 16, 2009; Revised December 4, 2009; Accepted December 10, 2009) 